\title{
Die Ned. Geref. Kerkorde 1962 en Sinodes: Die Dordtse Kerkorde aangepas by die eise van ons dag?
}

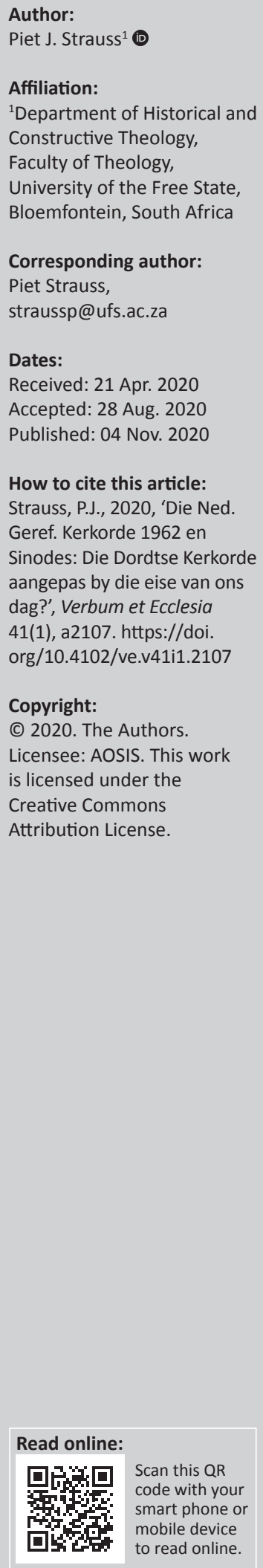

The church order of the Dutch Reformed Church 1962 and synods: The church order of Dordrecht adapted to our day? After the completion of their concept of the first church order for the whole Dutch Reformed Church (DRC), an order which was accepted by the first general synod of the DRC in 1962, one of the members of the drawing committee, J.D. Vorster, declared that this concept was a modern example of the church order of the Synod of Dordrecht in 1619 in the Netherlands: an order for modern times. The DRC all along associated with this synod in its acceptance of the Three Formulas of Unity as confessions of faith, and now wanted to extend this to its church order. An investigation into the articles or ruling of the DRC church order of 1962 on the existence and functioning of synods in the DRC shows that it was not totally in line with that of Dordtrecht. Apart from some issues on the agenda of the synods that constituted the general synod, as well as some points for the agenda of the general synod, the church order of the DRC took its own direction. In determining the delegation and agendas of synods, the church order of the DRC followed principles foreign to a reformed church polity. A reformation of these structures in our day will benefit the whole DRC: from the congregations to major assemblies.

Intradisciplinary and/or interdisciplinary implications: This article concentrates on church polity and the development of a church order in a reformed way - especially on the theme of assemblies in church. It also needs and stimulates the knowledge of general history and church history for a reformed church in South Africa which has ties with the reformed churches in the Netherlands.

Keywords: unique task of major assemblies; no duplication of synods in denomination; synods handle common affairs of congregations; church order of DRC influenced by church order of Dordt.

\section{Inleiding}

Vroeg in 1960 verklaar J.D. Vorster, 'n mede-skrywer en die eindredakteur van die eerste Kerkorde van die Nederduitse Gereformeerde Kerk (NGK) in algemene sinodale verband (NGKO-62) én die verkose kerkordeman ${ }^{1}$ of aktuarius by die eerste Algemene Sinode in 1962 (Langner 2007:87), dat die konsep van NGKO-62 wat aan dié Sinode voorgelê word, die 'Dordtse Kerkorde aangepas by die eise van ons dag' is (Vorster 1960:13). Daarmee impliseer Vorster dat NGKO-62 in die Nederlands-gereformeerde kerkordelike tradisie staan en na die Dordtse Kerkorde van 1618-1619 (DKO-1619) en die 16de-eeuse Kerkordes teruggevoer kan word (Pont 1981:70-186; Rutgers 1971:10). ${ }^{2}$ Immers, 'n ontleding toon dat sy kerkordelike rigting, hoofstukindeling (met die inleiding, ampte, kerkvergaderings, arbeid van die kerk, tug en betrekkinge van die kerk na buite) en die bewoording van sekere artikels, van die DKO-1619 kom (Strauss 2010:8; Van der Watt 1987:9).

Anders gestel, die Kommissie van Aktuarii van die verskillende sinodes wat in die Algemene Sinode in Oktober 1962 verenig, wil sien dat die NGK kerkordelik op die spoor van die Nederlandse (Nederduitse) gereformeerde kerke van die 16de eeu, loop. Hierdie kommissie

\section{Roussou (1979:44) praat van'n kerkregkundige.}

2.Deur sy geskiedenis blyk daar van tyd tot tyd 'n duidelike affiniteit vir die DKO in die NGK (Strauss 2010:7). Die Algemene Sinode van 1962 kies die Dordtse Drie Formuliere van Eenheid as gereformeerde belydenisskrifte en NGKO-62 met sy beweerde Dordtse 'konneksie' as kerkorde. Die eerste Sinode in die geskiedenis van die NGK, die Sinode van 1824, versoek die Kaapse goewerneur om naas sy eie Reglement ook die DKO-1619 te publiseer (Vorster 1960:14). In Engels lui die brief van die varsitter en sekretaris namens die Reglement ook die DKO-1619 te publiseer (Vorster 1960:14). In Engels lui die brief van die voorsitter en sekretaris namens die moderatore (dagbestuur) van hierdie Sinode dat die DKO a fundamenta Docus are bound to conform' is (volledige brief in Dreyer 1936:259). In 1937 best sy Wette en Bepalinge ook' $n$ hersiene (deur hierdie Sinode) 'Konsep van de Kerkorde van Dordrecht' - in Afrikaans - ter 'informasie' van die NGK te publiseer (NGK-OVS 1937:191). Twintig jaar later neem die Kaapse Sinode die Nederlands-gereformeerde gebruik van die woord 'kerkorde' en die hoofstukindeling van die DKO-1619 oor. Die Nasionale Sinode van Middelburg van 1581 is die eerste sinode in die Nederlands-gereformeerde tradisie wat afsonderlike artikels in ' $n$ kerkorde opstel (Biesterveld \& Kuyper 1905:95, 142). Volgens J.D. Vorster wat hierin 'n leidende rol speel, baan hierdie skuif van die Kaapse Kerk in 1957 die weg vir die eerste Algemene Sinode van die NGK, die Sinode van 1962, om dieselfde te doen (Vorster 1960:13). 
bestaan uit J.D. Vorster (Kaapland), H.D. du Toit (Natal), J.J. le Roux (Vrystaat), W.D. Jonker (Transvaal) en P.A. du Toit (Suidwes-Afrika) (NGK 1962:5-13).

Die vraag is nou: Loop NGKO-62 in sy bepalings oor sinodes - die sinodes van die ou Kaapland, Natal, die Vrystaat, die ou Transvaal en Suidwes-Afrika (tans Namibië) en die Algemene Sinode waarin hulle in 1962 verenig (Van der Watt 1987:9, 20-21), op die spoor van die DKO-1619? Is NGKO-62 hierin die DKO-1619 aangepas by die eise van die dag? Gebruik NGKO-62 dieselfde beginsels as die DKO-1619 vir die samestelling en werksaamhede van partikuliere of streeksinodes of net sinodes (die NGK-term vir hierdie soort sinodes van sy verband in die destydse provinsies van Suid-Afrika) én die nuwe Algemene of, soos dit deur ander gereformeerde kerke genoem word, nasionale Sinode?

Die Dordtse Kerkorde van 1618 artikel 29 voorsien vier vergaderings of 'kerkelijke samenkomsten' vir die regering van die Gereformeerde Kerk in Nederland: die kerkraad, 'classicale vergaderingen', 'particuliere' sinodes én die 'generale of nationale' sinode (vgl. teks in Pont 1981:179). Die NG Kerkorde 1962 sluit oënskynlik hierby aan met vier 'gewone kerklike vergaderinge' in NGK-verband: kerkraad, ring, sinode en Algemene Sinode (NGKO-62 artikel 18 in NGK 1964:5). Die naam 'Algemene Sinode' word in NGKO-62 deurgaans met hoofletters gespel omdat dit die eienaam van hierdie Sinode is (NGKO-62 artikels 18, 38-47 in NGK 1964:5, 8-10). ${ }^{3}$

En tog is daar verskille in die samestelling en werksterrein van hierdie sinodes.

In die DKO-1619 word die wyse van afvaardiging na die klassis, partikuliere en generale sinode trapsgewys gereël. Elke kerkraad vaardig as 'n kerkraad 'n gelyke aantal af na die klassis, elke klassis as 'n klassis 'n gelyke aantal na die partikuliere sinode en elke partikuliere sinode 'n gelyke aantal na die generale sinode. Die beginsel is dat gemeentes as gemeentes, klassisse as klassisse en sinodes as sinodes gelykwaardig is en dus as strukturele gelykes, afgesien van die getal lidmate, dominees of gemeentes daarin, in kerkverband opgeneem word. 'n Vergelykbare beginsel is dié van indiwiduele mense wat ryk of arm, slimmer of minder slim, pienk of geel, as mense op menslikheid of menswaardigheid, op gelykwaardigheid, aanspraak maak. Ten opsigte van die Algemene Sinode gaan NGKO-62 nou - in hoofsaak - van dieselfde beginsel uit. Die vyf provinsiale 'kerke of sinodes' wat die Algemene Sinode vorm

3.In die Nederlands-gereformeerde tradisie kry ons twee soorte sinodes. Die eerste is ' $n$ sinode wat tussen die klassis of ring en die algemene of generale sinode staan. Hiervoor word benamings soos streek-, provinsiale of partikuliere sinodes gebruik. Partikuliere sinodes wat gewoonlik ontstaan as die provinsiale sinode soos begrens deur staatkundige provinsies, te veel kerke of gemeentes vir so ' $n$ vergaderin hanteer en daarom onderverdeel. Die naam 'partikuliere' is 'n suiwerder kerklike term met sy kerklik bepaalde grense as die term 'provinsiaal' met sy nie-kerklike term met sy kerklik bepaalde grense as die term 'provinsiaal' met sy nie-kerklike staatsgrense. Hierby kom daar ' $n$ omvattende - dit sluit die totale kerkverband in nasionale, algemene of generale sinode soos bepaal deur die kerk self. Die DKO 1619 kies partikuliere sinodes en ' $n$ generale of nasionale sinode. Die NG Kerkord 1962 kies sinodes en 'n Algemene Sinode. Hoewel hierin situasiegebonde nam voorkom, is hulle nie so ver van mekaar nie (Pont 1981:179; NGK 1964:5; Straus 2004:108-109). Kerke wat terminologies verskil, kan met verskillende terme eventueel op dieselfde prinsipiële spoor as die DKO-1619 loop.
(NGKO artikel 36 in NGK 1964:7) tree toe as strukturele gelykwaardiges, afgesien van die getal lidmate of aantal gemeentes, met 'n gelyke aantal afvaardigdes na die Algemene Sinode.

Tog trek die nuk van 'n politieke demokrasie ook hier deur. In plaas van die gereformeerd Christokratiese benadering waar kerklike strukture soos gemeentes, ringe en sinodes as gelykwaardig met hulle eweknieë in die samestelling van die vergaderings van die kerkverband beskou word (Bavinck 1967:356: Strauss 2004:112), gaan die NGK 'n ander weg op. Omdat die Kaapse Sinode van 1962, sonder om te spesifiseer, meer lidmate (gemeentes?) as die ander sinodes het, bepaal NGKO-62 dat hy in plaas van 50 (met 25 predikante en 25 ouderlinge) soos die ander sinodes, 150 (met 75 predikante en 75 ouderlinge) na die Algemene Sinode afvaardig. Hoe daar by hierdie afgeronde getalle gekom word, blyk nie uit die konsep van NGKO-62 nie (NGK 1964:8). Dit gaan hier om 'n ongereformeerde beginsel dat die getal gemeentes of lidmate aan die Kaapse Sinode groter seggenskap op die Algemene Sinode sou gee as die ander sinodes (soos die getal kiesers in ' $n$ referendum of kiesafdelings in ' $n$ verkiesing?).

Boonop bepaal NGKO-62 artikel 30 en 33 (NGK 1964:6, 7) dat die aantal leraars van 'n gemeente en nie die gemeentes as strukturele gelykwaardiges nie, die getal afgevaardigdes per gemeente na ringe en sinodes - die meerdere vergaderings waarheen NGK-gemeentes afvaardig - bepaal (NGK 1964:6, 7: 'ring' is die NGK-term vir klassis, Strauss 2017). 'n Dominokrasie of oorheersing van die amp van dominee bepaal dus die getal afgevaardigdes per gemeente na meerdere vergaderings. Elke dominee moet - darem deur 'n ouderling vergesel word of een ouderling moet 'al' die dominees van die gemeente vergesel (NGK 1964:7). Die grootte van die afvaardiging word nie deur die gemeentes as die struktureel gelykwaardige draers van die kerkverband en sy vergaderings bepaal nie. ${ }^{4}$ Die vertrekpunt in die DKO1619 dat kerkverband ' $n$ verband van gemeentes as volledige kerke (ecclesiae completae) is en dat hierdie norm uit die samestelling en werk van meerdere vergaderings soos ringe, sinodes en die Algemene Sinode blyk, funksioneer nie in NGKO-62 nie (Strauss 1999:42,e.v., 2004:112-113).

Hierdie toedrag van sake beteken egter nie dat NGKO-62 ook van die ander gereformeerde bepalings in die DKO-1619 vir kerkvergaderings, afwyk nie. Daarop word teruggekom (NGKO artikel 18-25 in NGK 1964:5; Strauss 2010:52).

Oor die afvaardiging van kerkrade na ringe en sinodes met laasgenoemde 'n sinode van watter aard ook al is NGKO-62 op grond van hierdie kort ontleding dus nié by die DKO (DKO-1619) aangepas by die eise van 'ons' dag nie.

4.Die Kerkorde van die Protestantse Kerk in Nederland praat van alle kerklike vergaderings as 'ambtelijke' vergaderings of vergaderings waarin ampsdraers van vemeentes sitting neem (PKN-KO 2003.69). Meerdere vergaderings is egter nie gemeentes sitting neem (PKN-KO 2003:69). Meerdere vergaderings is egter nie ampsdraerswatmetamps-ofgemeentewerk, ditwil sê, metampswerk=gemeentewerk en tot die gemeente beperk, besig is nie, maar die gesamentlike of gedeelde werk van die gemeentes deur middel van hulle afgevaardigdes. Die meeste wat van afgevaardigdes gesê kan word, is dat hulle deur die kerkraad aangewys is as die best persoon vir die werk en/of agenda van die klassis of sinode. Werk wat nie noodwendig dié van ' $n$ ampsdraer, 'n ouderling of diaken, of ampswerk in die gemeente is nie (Strauss 2005:307). 
Inteendeel, die ontleding lê die noodsaak bloot van 'n behoorlike ondersoek na die samestelling en werk van sinodes in die DKO-1619 en NGKO-62 en die vraag of NGKO-62 in hierdie saak van 'n Nederlands-gereformeerde spoor geloop het. 'n Ontsporing wat vir 'n grondige ondersoek en 'n oplossing vra.

Dat hierdie probleem op die Algemene Sinode van 2002 aangevoel is, blyk uit sy opdrag aan die Algemene Regskommissie om die werksterrein van die sinodes en Algemene Sinode te ondersoek. So 'n ondersoek sou ook kon help om 'n verandering in kerkverband vir die NGK-familie in sy strewe na groter eenheid te vind (NGK [1962] 2002: 557-558; Strauss n.d.:92-105). Eventueel sou NGKO-2004 artikel 35-47 oor die samestelling en werk van die sinodes en Algemene Sinode egter onveranderd bly (NGK 1964:5-10; vgl. NGKO 2004:11-20, NGKO [2007] 2011:11-20).

\section{NG Kerkorde 1962 oor sinodes: die historiese aanloop}

Oor die samestelling en opdragte van sy sinodes en die Algemene Sinode het NGKO-62 'n ander pad geloop as wat gereformeerde kerke normaalweg loop. Eie, selfstandige sinodale verbande is na die uitspraak van die Loedolffsaak deur die Kaapse Hooggeregshof in 1862 mettertyd in, soos hulle na Uniewording in 1910 bekend sou word, die vier provinsies van Suid-Afrika, en na die Eerste Wêreldoorlog van 1914-1918, die mandaatgebied van Suid-Afrika naamlik Suidwes-Afrika, gevorm. Van der Watt verwoord die gebeure so: die Loedolffsaak het in die jare onmiddellik na 1862 gelei 'tot die konstituering van die Vrystaatse, Natalse en Transvaalse sinodes naas dié van die Kaapkolonie' (Van der Watt 1987:1). Hierdie sinodale verbande sou 'kerke' genoem word en struktureel los van mekaar funksioneer totdat die Federale Raad van NG Kerke (let op die term 'kerke') in 1905 ontstaan het. Met hierdie Raad is die kwessie van geen kerkverband nie, tussen vier sinodes naamlik die NG Kerk in Suid-Afrika (Kaapse Kerk), Natal (Natalse Kerk), OranjeVrystaat (Vrystaatse Kerk) en Transvaal (Transvaalse Kerk), omskep in 'n federale kerkverband. 'n Verband waarin die Federale Raad van Kerke oor gemeenskaplike sake - sake wat in beginsel by 'n algemene sinode tuishoort - nie bindende nie, maar adviserende besluite kon neem. En, aldus Van der Watt, hierdie Raad sou die NGK 'vir meer as vyftig jaar ... uitnemend' dien (Van der Watt 1987:1). Immers, die sinodes wat hier verteenwoordig is, was in belydenis, kerkinrigting én die belewenis van die kerklike omgewing een. Daarom was die Raad 'n platform waarop die eenheid van die hele NGK in kerklike sake bevorder en uitgedruk is. Nie 'n meerderheidstem nie, maar samestemming uit oortuiging die doel van oorlegpleging in die kerk as 'n geloofsverband wat bou op geloofsoortuigings - sou die deurslag gee. Met die algemene sinodale verband in die NGK in 1962 sou die Sinode van Suidwes-Afrika hom by hierdie vier sinodes aansluit as 'n vyfde sinode (Van der Watt 1987:14).

Teen hierdie agtergrond sou die algemene sinodale verband van die NGK met sy Algemene Sinode in 1962 vorm. Om die samestelling en verloop van dié vergadering te verseker, is NGKO-62 op 11 Oktober 1962 is vooraf by 'n konvensie aanvaar waarna die Algemene Sinode gekonstitueer het (Van der Watt 1987:14-15).

Skrywers oordeel dat name soos samestellende kerke of 'sinodes' en Algemene Sinode (NGK 1964:7) 'n aanduiding is dat hierdie instansies met behoud van hulle vroeëre bevoeghede as selfstandige sinodes in die nuwe 'algemene' sinodale verband verenig het en dus - dit is 'n gevolgtrekking wat gemaak word - die gevaar geloop het om teen die DKO artikel 30 (Pont 1981:179) soos verwoord in NGKO-62 artikel 22 (NGK 1964:7) in, te dupliseer. Die gevaar is dus dat hierdie duplisering sinodes in houding en werk teen die Algemene Sinode kan opstel en verdeeldheid in die NGK kan veroorsaak. Kleynhans oordeel dat die samestellende sinodes van die Algemene Sinode 'in 'n mate hul selfstandigheid, met hulle eie bepalinge in sake soos die sendingarbeid, die diens van barmhartigheid, evangelisasiewerk, jeugarbeid en ander plaaslike en huishoudelike aangeleenthede' behou het (Kleynhans n.d.:150). Soos voorheen kon hulle hieroor besluit én kerkordelike bepalings en reglemente vir die werk opstel, alles binne die raamwerk van NGKO-62 (Kleynhans n.d.:150). Van der Watt wys daarop dat die gebruik van die naam 'sinode' die feit verwoord dat NGKO-62 in sy bepalings oor sinodes en die Algemene Sinode, van die sake van voor 1962 oorgedra het na die sinodes in die nuwe algemene sinodale verband. Die samestellende sinodes het die kern van hulle werksterrein in die nuwe algemene sinodale verband behou. Hulle profiel het nie verander nie (Van der Watt 1987:9).

\section{NG Kerkorde 1962 oor sinodes: die werksterrein}

So bepaal NGKO-62 artikel 35a dat sinodes bepalinge en reglemente vir hulle werk opstel. Op die oog af klink hierdie bepaling billik. Sinodes moet as mondige kerkvergaderings op hulle terrein, of in die werk aan hulle toevertrou, die sake Bybels kerklik kan stuur en doen. Die vraag is egter: Watter maatstaf is daar om 'n noodsaaklike unieke agenda vir hierdie vergaderinge te bepaal? Hanteer die sinodes van die NGK nou sake wat slegs hulle, sonder 'n duplisering met die Algemene Sinode, op die agenda het? In artikel 35b word wel vaagweg bepaal dat sinodes alles wat die plaaslike kerke in die gebied gemeen het, moet behartig met die uitsondering van kwessies wat by die Algemene Sinode tuishoort.

Oor hierdie saak is daar in gereformeerde kerke in die algemeen 'n vloeibaarheid omdat die agenda van dié sinodes sinodes - gereformeerde kerke noem dit partikuliere of streeksinodes en 'n generale of algemene sinode (Strauss 2004:119,123) - nêrens of vir almal op een punt gesaghebbend vasgelê word nie. Gesien die beginsel dat 'n kerkorde sake nie moet reglementeer om die voorskrifte van die Bybel vir die kerklike lewe te verduister nie en dat die onderskeid tussen partikuliere en algemene sinodes in die geskiedenis van die gereformeerde kerke nie gemaklik en heeltemal opgelos is nie, moet ' $n$ kerkorde in elke geval by beginsels, raamwerke of rekbare sake bly. 
Uit NGKO-62 artikel 43 blyk dit dat 'n sinode in die NGK self - sonder raadpleging na buite - besluit wat hy hanteer en wat by die Algemene Sinode hoort. Hier lê egter 'n wasigheid wat nie waarborg dat NGKO-62 artikel 22 nié in gedrang kom nie. Watter sake moes by 'n mindere vergadering afgehandel gewees het? Boonop is dit 'n vraag watter sake gemeentes of kerke gemeen het en wat hulle vir hulself kan uithou (Strauss 2010:72). Moet dit nie hier eerder oor unieke sake gaan wat die gemeentes in rings- of sinodale verband saam móét aanpak om iets daarvan te maak nie? Van der Watt maak die stelling dat NGKO-62 met die naam en take van sy 'sinodes' afstuur op streeks- of partikuliere of, gesien voor 1962, provinsiale sinodes. Terme wat kerkordelik beter oorkom as die ongekwalifiseerde, vae 'sinode' (Van der Watt 1987:9).

Artikel 35c raak aan 'n opdrag wat in die NGK-verband duidelik by die sinode tuishoort wanneer hy die opleiding en legitimasie van predikante aan die sinodes toevertrou. Hierdie kwessie is te groot en te omvangryk vir 'n ring en vir die praktiese uitvoering daarvan 'te ver' van die Algemene Sinode. Laasgenoemde kan wel sorg vir die vereistes van die opleiding en beroepbaarstelling (legitimasie) van predikante omdat dit alle gemeentes raak en gemeenskaplike standaarde vereis. Dit gaan immers oor leraars wat na alle gemeentes in die NGK beroepbaar is. Werk binne sy ressort onder barmhartigheid, jeug, sending en evangelisasie hoort ooreenkomstig artikel $35 \mathrm{~d}$ by die sinode, maar binne die 'bepalinge' van die Algemene Sinode. Hierdie werk het voor 1962 by selfstandige sinodes gelê ten spyte van Van der Watt se stelling dat 'die beginsel van desentralisasie' by NGKO-62 voorop staan (Van der Watt 1987:9). Die Algemene Sinode maak nou bepalinge hiervoor, maar sinodes gaan met die uitvoering daarvan voort soos vroeër.

Die DKO-1619 gee in geen artikels bepalings vir die werksterrein van die partikuliere sinode nie (Biesterveld \& Kuyper 1905:238-239; Pont 1981:181-182). Tog verskaf die Nederlands-gereformeerde tradisie stof vir hierdie punt.

Ten spyte van die vaagheid oor die onderskeid in werksterrein tussen partikuliere en algemene sinodes in gereformeerde kerke, lewer 'n ondersoek na hierdie saak goeie vrug. Die agendapunte van partikuliere sinodes in Nederlandsgereformeerde kerke wat kerkordelik verantwoord is, verskil onderling, maar kan tog opgesom word onder drie hoofde: advies vir en appèlle van klassisse of ringe, die verligting van die opdrag van die algemene sinode ten opsigte van gemeenskaplike sake deur kwessies te hanteer wat te maklik na die algemene sinode deurgegee word en die gesamentlike werk van die gemeentes in die ressort van die partikuliere sinode (NGK [1962] 2002:289-290; Strauss 2004:123). Eie aan die aard van dit waaroor dit hier gaan, gee hierdie woorde algemene aanduidings van punte wat met wysheid en oorleg in kerkverband hanteer moet word.

Die sake wat tuishoort onder die versoeke om advies van die klassisse is sake waarvoor partikuliere sinodes in gereformeerde Nederland, soos hulle genoem is, swarigheidsdeputate gebruik het. Partikuliere sinodes het 'n belangrike taak in dié verband verrig deur hierdie deputate wat klassisse 'bystaan' in moeilike sake en swaar omstandighede (Nauta 1971: 211-212; Pont 1981:182).

Toegepas op sinodes in NGKO-62, is dit duidelik dat dit op spore loop wat in kerke voorkom in die Nederlandsgereformeerde tradisie soos wêreldwyd versprei. Moontlik mik NGKO-62 artikel 35f met sy sake wat by wyse van beroep voor hom gebring word, op genoemde advies en appèlle. Die NG Kerkorde 1952 (NGKO-52) artikel 35b bepaal dat sinodes alle sake wat die samestellende gemeentes of 'plaaslike kerke' gemeenskaplik het, aanpak en nie moet bots met die kwessies wat die Algemene Sinode hanteer nie. Onduidelikheid oor presies watter sake by watter sinode voorkom, kan egter nie ontken word nie. Tog maak hierdie artikel NGK-sinodes bedag op hulle eie verantwoordelikheid en op 'n sinodale laksheid wat moeilike sake met 'n vou van die hande deurgee na die Algemene Sinode. Eie bepalinge vir of besluite oor eie werk en die doen van die werk self, val onder die gesamentlike werksaamhede van die betrokke gemeentes. Die gevaar van 'n reglementering van die werksaamhede moes die kwessie van die opstelling van kerkordelike bepalings deur sinodes, egter voorkom het (vgl. NGK-OVS 1999:1-65 wat reglementering uitskakel). Finansies vir eie werk - NGKO-62 artikel 35e - en vir die funksionering van die Algemene Sinode, is in die NGK se algemene sinodale verband onvermydelik (NGK 1964:7).

Die sinodes van NGKO-62 kan met hierdie bepalings oor hulle opdrag én'n vernuwing aan die hand van gereformeerde beginsels of vertrekpunte in hulle samestelling, omgesit word in werkbare partikuliere of streeksinodes; partikuliere sinodes wat verenig rondom en gemotiveerd werk aan 'n eie roeping. Albly die 'ou provinsiale sinode', soos ou patriotisme en 'n ou lojaliteit vir ou provinsiale rugbyunies, by die NGK steek. Nederduitse Gereformeerde Kerk-Afrikaners het mos 'n neiging om ou sentimente lewend te hou.

Die aantal meerdere vergaderings en soorte sinodes in 'n gereformeerde kerkverband hang saam met die grootte en werksaamhede van die verband. Dit gaan nie om 'n vaste getal, struktuur en werksterrein vir meerdere vergaderings nie, maar 'n diskresionêre opsie van die gemeentes in hierdie verband (Strauss 2004: 14, 2010:114). 'n Uitsondering is die vergadering naaste aan die gemeentes of naburige kerke (die 'genabuurde kerken' van die DKO-1619 artikel 41): die klassis of, in NGK-taal, die ring (Pont 1981:180). Hierdie vergadering het die standaardopdrag om die geestelike gesteldheid van die gemeentes in sy ressort pastoraal te versorg as die roeping van hierdie gemeentes teenoor mekaar. Daarom word die belangrikste werk van 'n klassis kerkvisitasie of die pastorale versorging van gemeentes genoem (Pont 1981:181). In 'n kleiner kerkverband kan hierdie opdrag aan 'n gesamentlike vergadering van die verband gegee word wat die taak van die klassis of ring plus dié van 'n gekombineerde vergadering of sinode, hanteer. Ringe in die NGK is eers na sy eerste Sinode in 1824, in 1826, 
ingestel sodat die sinode van 1824 die taak van die ring ook op sy agenda gehad het (NGK in ZA 1857:7).

\section{NG Kerkorde 1962 oor sinodes: die samestelling}

Oor die samestelling van die ringe en sinodes het die NGK 'n eie pad geloop. 'n Pad wat moontlik teruggevoer kan word na Calvyn (1509-1564) en die Gereformeerde Kerk in Genève. Die feit dat alle predikante in hierdie gemeente by die regering van die gemeente betrokke was, het 'n spoor gelaat vir die Franse of Paryse Kerkorde van 1559 om dieselfde beginsel deur die kerk te handhaaf. Hierdie Kerkorde het in artikel 3 en 5 bepaal dat elke leraar van 'n gemeente op 'n colloque ('n soort klassis) of 'n sinode deur 'minstens één ouderling of diaken van elke gemeente of provinsie' vergesel word (Pont 1981:50; Strauss 1989:11). Calvyn is die erkende geestelike vader van gereformeerdes - ook in Nederland (De Jong 1987:207, 209e.v. 219-225e.v.).

Daar is reeds op die samestelling van die DKO-1619 artikels 41, 47, 50 en NGKO-62 artikels 30, 32 en 38 van meerdere vergaderings gewys. Die DKO gebruik die trapsgewyse afvaardiging met 'n gelyke verteenwoordiging van die gemeentes na die klassisse, van die klassisse na die partikuliere sinodes en van partikuliere sinodes na die nasionale sinode. Die naam 'nationale synode' in die DKO 1619 hang saam met Nederland se staatkundige, nie-kerklike grense $^{5}$ as die land waarin die ou Gereformeerde Kerk hom bevind het. Die DKO reël ook die gelykheid van lerende en regerende ouderlinge by afvaardiging na meerdere vergaderings (Pont 1981:179-182; vgl. Engelhard \& Hofman 2001:283; Kruger et al. 1966:289, 290, 307). So gee die Gereformeerde Kerk in die 'lage landen' uitdrukking aan die anti-hiërargiese stelreël dat geen gemeente of kerk, leraar, ouderling of diaken sal heers oor 'n ander kerk of amp nie. Hovius maak gewag van die anti-hiërargiese bepaling in die eerste artikel van die Disciplines Ecclesiastique of Kerkorde van die Sinode van Parys in 1559 as 'n 'canon aureus' of goue reël in gereformeerde kerke en kerkregering (Strauss 1989:2). Die eerste Nasionale Sinode van die Nederlandsgereformeerde Kerke, die Sinode van Emden van 1571, bevat dieselfde bepaling in die eerste artikel van sy acta of notule (Biesterveld \& Kuyper 1905:35).

Hierteenoor werk NGKO-62 met die getal predikante in die gemeente plus een of 'n gelyke aantal ouderlinge of, sedert 1986 (NGKO-86:8), 'n gelyke aantal ouderlinge en/of diakens (diakens maak nou die vroeëre getal ouderlinge vol) vir elke dominee (NGK in ZA 1857:1, 29; NGKO-62 artikel 30, 33, 38; NGK 1964:6-8). Behalwe dat gelykheid tussen ouderlinge en diakens hiermee in 1986 uitgeskakel

\footnotetext{
5.Teenoor die tradisionele Gereformeerde Kerke in Nederland of Suid-Afrika, laat die Algemene Sinode van 1962 staatkundige nie-kerklike grense as ' $n$ agtervoegsel tot sy naam weg. sy naam weg. Die rede hiervoor is waarskynlik tweerlei. Die NGK wou finaal breek met die uitspraak in die Loedolffsaak en die staat kan in beginsel nie die uitdra van die Evangelie tot sy eie grense beperk nie. Die Woord van God en die NGK as drae daarvan kan nie staatkundig ingeperk word nie (NGK [1962] 2002:39, 135, 232). Teenoor die Ordonnansie 7 van 1843 waarop die Loedolffsaak gebou is, het die Algemene Sinode gewys op die NGK wat van sy onstaan af 'in eie kring 'n selfstandige bestaan gevoer het' (Van der Watt 1987:12).
}

word (vir ampsgelykheid tussen afgevaardigde leraars, ouderlinge én diakens, vgl. Nauta 1971:191, 208, 217), verander hierdie reëling nie aan die saak dat die getal predikante in die gemeente en nie die gemeente as struktureel gelykwaardig met ander gemeentes nie, die grootte van afvaardigings na die meerdere vergaderings bepaal. Vanuit 'n liberaal demokratiese oogpunt is dit ondenkbaar dat 'n gemeente van 200 lidmate dieselfde stemkrag as 'n gemeente van 1500 sal hê. Tog wys Bouwman daarop dat die kwessie van groot en klein gemeentes ook in die Gereformeerde Kerk in Nederland in 1578 aanwesig was, maar nie die reformatoriese konstante van die antihiërargiese én strukturele gelykwaardigheid van gemeentes vervang het nie (Bouwman 1985:137).

Volgens die geldende Kerkorde van De Mist in 1824 kon die NGK-Kaapstad twee predikante en twee ouderlinge na die Sinode stuur. Hy het egter al drie sy dominees - in 1824gestuur vergesel van twee ouderlinge (NGK in ZA 1857:1). Met sy ouderlinge het die NGK-Kaapstad by die Kerkorde gebly, maar met sy dominees die tradisie gevolg: 'n ongemotiveerde teenstrydigheid. Deur sy aanvaarding hiervan by konstituering het die sinode ingeval by die historiese neiging dat die verteenwoordiging van gemeentes bepaal word deur hulle aantal dominees of 'n dominokrasie. Hierdie tradisie sou vanaf 1824 deur NGKO-62 tot by NGKO2019 loop (NGK in ZA 1857:1; NGKO-62 artikels 33, 38 in NGK 1964:7.8; NGKO 2015). Die Sinode van 1824 was volgens Kerkorde dus onwettig saamgestel. Boonop was hy verbind tot 'n nie-reformatoriese hiërargiese tradisie ten opsigte van die gemeentes omdat Kaapstad met sy drie dominees as die kerklike 'Hoofdplaats' (ook met 'n hoofletter) en daarom 'n uitsondering beskou is (NGK in ZA 1857:1; Kleynhans n.d.: 218). ${ }^{6} \mathrm{Na}$ die uitspraak in die Loedolffsaak in 1862 was die NGK by die afbakening van die grense van gemeentes en sinodes uitgelewer aan die, soms kerklik ongunstig grense van die staat. Met die verdeling van die Transvaalse Kerk in vier en Kaapse Kerk in drie sinodes in die laaste helfte van die 20ste eeu, is sinodaal kerklike grense egter sonder eksterne dwang vasgestel wat 'n goeie oefening vir die verdeling en vastelling van die grense in kerklik berekende partikuliere sinodes kan wees. Boonop sal die NGK by die Gereformeerde Kerke in Suid-Afrika (GKSA) 'n voorbeeld van so iets onder gereformeerdes in Suid-Afrika vind waarmee hy sy eie pogings na oorleg kan vergelyk. 'n Oorleg waarvolgens hy sy kerklike trots in sy sak moet steek. Daarby kompliseer staatkundige grense sommige lidmate se lidmaatskap van 'n gemeente omdat die naaste gemeente en hulle leefgemeenskap net oor die grens is terwyl hulle kerklik veel verder 'n heenkome moet vind.

\footnotetext{
6.By die konstituering van die Sinode van 1824 sou die praeses of 'Eerw. Heer' J.C Berrangé, aldus die acta, die sinode wettig verklaar ten spyte van die 'Eerw. Kerkeraad aan de Hoofdplaats' Kaapstad se onkerkordelike nie-gereformeerde drie predikante en twee ouderlinge. Op die teenwoordigheidslys in die acta verskyn Kaapstad se verteenwoordigers ook eerste omdat dit die oudste gemeente is (NGK in ZA 1857:1). Daarna volg die ander gemeentes in ' $n$ volgorde wat van die (Natum van stigting vir hulle plasing in die a van stigting ir hullor tradisie gevestig wat vir jare die volgorde sou bepaal van hoe die afgevaardigdes van gemeentes in sinodes sitting neem en die name van gemeentes - binne hulle sinodale verbande sonder respek voorkeur aan 'n lewelose alfabet bo ' $n$ lewende historiese bewussyn gee, sou egter ' $n$ abrupte einde hieraan bring (NGK 2016). Moontlik sit die skuldige iewers gesigloos in 'n studeerkamer of ' $n$ kantoor.
} 
Op die vraag of NGKO-62 met sy samestelling van sinodes wel die DKO-1619 aangepas by die eise van 'ons' dag is, moet negatief geantwoord word. Tog kom NGKO-62 met sy werksaamhede van sinodes naby aan die Nederlands gereformeerde tradisie. Intussen lei die sinodes se reg om kerkordebepalings binne die artikels van die Algemene Sinode oor dieselfde soort kerklike werksaamhede te maak, tot 'n ongesonde duplisering én die verontagsaming van NGKO-62 artikel 22 dat meerdere vergaderings slegs sake hanteer wat daar tuishoort of wat mindere vergaderings nie kon afhandel nie (NGK 1964:5).

Die NG Kerkorde 1962 dra met die wyse waarop sy sinodes saamgestel is én funksioneer 'n verlede waarin trekke van 'n Nederlandse gerofmeerde aanslag ontbreek en hy ongemotiveerd sy eie geskiedenis as norm gebruik. Sinodes se samestelling en werksaamhede word só gedoen omdat dit so gedoen is, nie omdat die NGK kerkregtelik reformatories ingestel is nie. 'n Geskiedenis wat mank gaan aan gereformeerd kerkregtelike analises én waarvan hy hom emosioneel moeilik ontworstel.

\section{Die NG Kerkorde 1962 oor die Algemene Sinode: werksaamhede}

Juis met die oog op die uitskakeling van duplisering voer gereformeerde kanonici aan dat 'n algemene of generale sinode daardie sake moet hanteer wat die gemeentes in hulle mees algemene verband gemeenskaplik raak. Hierdie beginsel verwoord die eie unieke invalshoek vir algemene sinodes. Dit gaan oor sake wat die gemeentes vry laat én stimuleer om hulle funksie as volledige kerke te vervul (Bouwman 1985:196; Nauta 1971:225); vry laat om mondige gemeentes te wees en gemeenskaplike sake in 'n gerespekteerde, geloofwaardige kerkverband met oortuiging aan te pak. Om die kerklike lewe - in die gemeente sowel as die kerkverband - Bybelsgebonde en juis van daaruit, gereformeerd innoverend te voer.

Vir Bouwman gaan dit by algemene of generale sinodes om vergaderings wat die eenheid, krag en goeie gang van die kerklike lewe bevorder en 'n egte, begronde leefruimte aan die mindere vergaderings in dié verband op hulle terreine gee. Generale sinodes tref reëlings wat 'voor alle kerken (gemeentes) kracht bezitten'. Vir die agenda van 'n generale sinode dink hy aan sake soos die vasstelling van die belydenis, maatreëls vir orde en tug in die kerk, gesamentlike - van die gemeentes - kerklike werk en die reëling van die behoorlike opleiding van predikante(Bouwman 1985:211e.v.). Van Wyk sluit hierby aan wanneer hy die werk van die nasionale sinode in die Gereformeerde Kerk in Nederland in die 16e eeu opsom: Die handhawing van die belydenis en die kerklike dissipline, die vasstelling van die kerkorde, die inrigting van die openbare erediens en maatreëls vir die algemene welstand van die gemeentes (Van Wyk 1981:82). Met sy verwysing na die taak van die generale sinode van die Gereformeerde Kerke in Nederland in 1971 wys Nauta op die vasstelling van die amptelike of kerklik erkende
Bybelvertaling, die belydenisskrifte van die kerk, die kerkorde, die Psalm- en Gesangboek en die liturgiese orde in eredienste (Nauta 1971:225e.v.).

As die Algemene Sinode van die NGK in 1962 NGKO-62 artikel 43 wat sy eie take aanstip, aanvaar, loop hy in artikel 43 a en b die Nederlands gereformeerde pad van die Kerkorde van die Gereformeerde Kerke in Nederland 1959 (GKNKO-1959). Laasgenoemde eggo uitkenbaar in NGKO62 artikel 43 a en b: die vasstelling van die 'amptelike' Bybelvertaling, die belydenisskrifte, die kerkorde, 'liturgiese formuliere en gebruike', die orde van eredienste en die Psalm- en Gesangboek (vgl. Engelhard \& Hofman 2001:275; Nauta 1971:225; Van Dellen \& Monsma 1967:185, 348-349;).? In die volgende take $(\mathrm{c}-\mathrm{j})$ duik die historiese situasie van die NGK egter op, die behartiging van die onbepaalde gemeenskaplike belange van NGK-sinodes soos vantevore deur gefedereerde of federale 'liggame' binne die Raad van Kerke hanteer - hier raak die ooreenkoms tussen die take van die sinodes en Algemene Sinodes weer vaag; die vasstelling van die vereistes vir die opleiding van dominees en die ondersteuning daarvan in praktyk waar nodig - 'n staande NG-wantroue in die mondigheid en vermoë van mindere vergaderings wat lei tot die sentralisering van kerklike gesag in sogenaamde 'hoër' vergaderings soos sinodes en nou die Algemene Sinode; ondersteuning aan sinodes waar nodig in evangelisasie, barmhartigheid, sending en so meer - nog 'n openbaring van genoemde wantroue; die bepaling van beleid vir die werk van sinodes - terwyl hulle as mondige kerkvergaderings self beleid op hulle eie werksterrein moet kan vasstel; sake wat nie deur sinodes of mindere vergaderings afgehandel kon word nie en na die Algemene Sinode verwys word; beheer oor kerklike publikasies en ekumeniese verhoudinge met ander kerke ${ }^{8}$ (NGKO-62 artikel 43 in NGK 1964:9).

Die take wat ooreenstem met dié van die Generale Sinode van die Gereformeerde Kerke in Nederland (GKN) in GKNKO-1959, punte a en b, sluit aan by die Nederlands gereformeerde tradisie wat teruggaan tot by die DKO-1619.

Oor die vasstelling van die belydenisskrifte vereis NGKO-62 artikel 44 'n tweederdemeerderheid van elke sinode - sonder die Algemene Sinode (NGK 1964:9). Maar, met die proses wat die NGK later sou volg met eenheidwording in die NGKfamilie word hierdie tweederdemeerderheid van elke sinode verbreed na 'n tweederdemeerderheid van 'twee derdes van alle kerkrade' (NGKO-2004:19). Daarmee sê NGKO dat 'n gereformeerde kerk as kerk nie met 'n getallemeerderheid moet probeer oortuig of in feite oordonder nie, maar dat kerklike besluite na oortuiging volg. Anders kom daar spanning en verdeeldheid (Strauss n.d.:100).

7.Die Christian Reformed Church in sy Kerkorde (CRCN-KO) 1965 as 'n hersiene CRCN KO neem GKNKO-1959 ook deeglik in ag as 'n hersiene DKO (Engelhard \& Hofman 2001:14-15).

8.In min of meer dieselfde era (1965) reël die Christian Reformed Church in sy Kerkorde (CRCN-KO) artikel 49 ook dat sy sinode as die mees algemene vergadering Kerkorde (CRCN-KO) artikel 49 ook dat sy sinode as die mees algemene vergadering
van die verband die ekumeniese verhoudinge met ander kerke behartig (Engelhard \& Hofman 2001:287). 
Waar die Nederlands gereformeerde tradisie uitgaan van mondige kerkvergaderings wat elk die werk van die kerk op hulle terrein doen, openbaar NGKO-62 'n kwalik verborge wantroue in die mondigheid van mindere vergaderings. Hierdie ingesteldheid word 'n emosionele houding dat die eintlike NGK 'hoër' in sy Algemene Sinode setel. Volgens hierdie houding besluit die NGK eintlik deur sy Algemene Sinode wat van 'bo' af kerklike standpunte en werksaamhede kontroleer en finaliseer. Hierdie gesentraliseerde kerklike bevoegdheid skuil in die bewoording van sommige opdragte van die Algemene Sinode soos gevisualiseer in NGKO-62 artikel 43: 'die behartiging van die gemeenskaplike belange van sinodes', 'die ondersteuning van predikantsopleiding waar nodig', 'die ondersteuning van sinodes in hulle werk' en 'die bepaling van beleid'. Die effek van so 'n houding is tweërlei. Eerstens skaaf dit aan die waardigheid, selfbeeld en kundigheid van mindere vergaderings, so asof hulle nie 'n sinvolle kerklike of geloofsbydrae kan lewer nie. Asof hulle kerklike posisie en nie Bybelse argumente nie, moet bepaal of iemand na hulle luister. Tweedens verskuif hierdie formulering die hart van kerkwees na 'n enkele, onsigbaar vir baie, vergadering wat met tussenposes vergader en nie deurgaans 'n plaaslike geloofsliggaam vorm nie. Wie die gemeente as volledig kerk of die kern van kerkverband ontken, ontneem die kerk van hierdie werktuig en mis die krag van die geestelike wapenrusting wat omrede die suiwere bediening van die Woord, die sakramente en die tug en deur die Gees toegerus, hier ontstaan (Ef 6). Die wegpak van die kerklike ekumene in die kas van die Algemene Sinode in 1962 het negatief ingewerk op kerkeenheid wat by gemeentes as die uitstalvenster van kerkwees moet begin.

\section{NG Kerkorde 1962 oor die Algemene Sinode: samestelling}

Soos getoon, vertoon NGKO-62 oor die samestelling van die Algemene Sinode die invloed van meer as een motief. Aan die een kant is daar sprake van die gereformeerde antihiërargiese trapsgewyse manier van afvaardiging (vgl. Visser 1999:214). Aan die ander kant loop daar 'n liberaal demokratiese motief deur wat hom bedien van onduidelike maatstawwe: afgeronde getalle gebaseer op 'n onbevestigde aantal lidmate, predikante of gemeentes. Daar is daarop gewys dat die 50 afgevaardigdes uit elke samestellende sinode by die Kaapse Sinode of die NGK in Suid-Afrika na 150 vermeerder is: die helfte predikante en die helfte ouderlinge. Die onduidelikheid was of hierdie ekstra 100 by die Kaapse Sinode op 'n groter aantal gemeentepredikante of gemeentes gebaseer was. Die rede kom nie in die acta van die Algemene Sinode van 1962 voor nie. Ook nie in die notule van die konvensie van 11 Oktober 1962 wat NGKO-62 aanvaar het om die eerste Algemene Sinode glad te laat verloop nie. Hoe dit ook al sy, hierdie 50 teen 150 moes as getalle op een of ander wyse op demokratiese oorwegings gebaseer gewees het. Of kon dit moontlik 'n toegewing in 'n oomblik van onderlinge welwillendheid en vertroue gewees het?
Hierdie situasie sou by die Algemene Sinode van 1974 verander. Die NG Kerkorde 1974 (NGKO-74) artikel 38 het nou bepaal dat die Kaapse Sinode nie meer 150 afgevaardigdes nie, maar 100 stuur: die helfte predikante en die helfte ouderlinge (NGKO 1974:8). Teen 1986 was daar meer sinodes en is die saak nogeens verander. Elke sinode, waaronder die sinodes van Wes-, Noord- en Oos-Kaap, kon nou 40 afgevaardigdes stuur: 20 predikante en 20 ouderlinge en/of diakens. Die strukturele gelykheid van sinodes as gelykwaardige kerklike strukture wat saam 'n algemene sinodale verband vorm, was herstel (NGKO 1986:9). Die gereformeerde trapsgewyse manier van afvaardiging van die sinodes na die Algemene Sinode is konsekwent deurgetrek (Pont 1981:180-182; vgl. Engelhard \& Hofman 2001:267; Visser 1999:206, 212, 214).

Op die vraag hoe hierdie sinodes ontstaan hulle in die Algemene Sinode bevind, afgesien van die aanvanklike vyf, antwoord NGKO-62 artikel 32: die groepering van die sinodes kan gewysig word op versoek van die 'betrokke sinode'. Die norme vir 'n nuwe sinode is dat hy geografies 'n eenheid vorm en maklik kan vergader (NGK 1964:6; NGKO 1974:8). ${ }^{9}$ Drie opmerkings moet op dié punt gemaak word. Eerstens vorm hierdie sinodes skynbaar nie primêr om 'n geestelike eenheid rondom sy opdrag of agenda te wees $^{10}$ of om kerklike of bedieningsredes nie. ${ }^{11}$ Hoewel ongekwalifiseerd speel, geografies staatkundige grense in 1962 en daarna steeds 'n deurslaggewende rol in die NGK. Die naam NGK sonder 'n geografies staatkundige agtervoegsel was tot die algemene sinodale verband beperk, terwyl sinodes meestal met 'n staatkundige agtervoegsel in hulle name volhard het. Tweedens maak NGKO-62 slegs ruimte vir 'n nuwe sinode binne 'n bestaande sinode. 'n Alternatief sou meer sinodes by die saak moes betrek. Derdens moet die sinodes wat in 1962 kragtens NGKO-62 die algemene sinodale verband gevorm het, in beginsel reeds ' $n$ geestelike eenheid wees en maklik vergader sodat hierdie rede alleen nie bepalend kan wees vir nog 'n sinode nie. Die vraag na wat sulke sinodes moet hanteer wat binne die kerkverband nodig is, wat so 'n sinode moet doen as 'n sinvolle kerklike instelling in die gebied, word nie in NGKO62 gevra of beantwoord nie. Die hele situasie skep die vermoede dat die NGK hom in 1962 emosioneel en geestelik nie heeltemal losgemaak het van sy soos voorheen beeld van sinodes nie. Die geografiese element in die name van die meeste van die huidige 10 sinodes, bevestig hierdie waarneming in die 21 e eeu.

9.Die Kerkorde van die Gereformeerde Kerke in Nederland van 1959 (GKNKO-1959) artikel 53 gee ook die vasstelling van partikuliere sinodes aan die generale sinode. Partikuliere sinodes in die GKN word egter tot tussen drie en ses klassisse beperk (Nauta 1971:206)

10.Gereformeerd beskou, is kerkeenheid ten diepste ' $n$ eenheid rondom ' $n$ bepaalde belydenisrigting se vertolking van die suiwere bediening van die Woord, sakrament en tug. Sy belydenisgrondslag is immers 'n bepaalde kerkverband se akkoord van kerklike gemeenskap (Smit 1984:64).

11.Gereformeerd beskou, is kerkverband ' $n$ instrument van en vir gemeentes. Kerkverband moet gemeentes stimuleer om nog beter volledige kerk te word en nie daaraan afbreuk doen of gemeentes in byna lewelose posbusse van besluite en opdragte verander nie (Biesterveld \& Kuyper 1905:36; Strauss 2010:65). 


\section{NG Kerkorde 1962: bepalings vir alle kerkvergaderings}

Dit is reeds aangetoon; NGKO-62 sonder vier 'gewone kerklike vergaderinge' as vergaderings van die NGK uit: 'Kerkraad, Ring, Sinode en Algemene Sinode' (NGK 1964:5).

Daar is reeds verwys na die opvatting onder talle in die NGK dat meerdere vergaderings en veral sinodes, 'n hoër 'kerklike status' as kerkrade en ringe het. Dat hierdie 'hoër' aan sulke vergaderings groter gesag gee en dat hulle uitsprake meer gewig dra. Hierdie houding is egter nie gebaseer op NGKO-62 artikels 18-47 vir vergaderings in die NGK-verband nie. Bepalings wat handel oor die gesag van kerkvergaderings, hulle eie invalshoek op sake en hulle manier van doen as kerklike instellings.

Die NG Kerkorde 1962 erken die norm van GKNKO-1959 en bepaal dat elke kerkvergadering 'na sy eie aard' met gesag funksioneer deur Christus verleen. Dat die gesag van die ring oor die kerkraad dieselfde is as dié van die sinode oor die ring en die Algemene Sinode oor die sinode. Hierdie bepaling impliseer drie sake. In die eerste plek is Christusgesag Woordgesag; 'n gesag wat in die praktyk erken word as die Bybel, wat die werkende norm vir kerk en lewe is. Woordgesag wat deur elke kerkvergadering op sy aangewese terrein eerbiedig moet word; Woordgesag wat meebring dat sy kerkordelike taak 'n roeping van die Here is. Dat hierdie roeping van die Here hom aanspoor en stimuleer om sy werk as vergadering reg aan te pak. In die tweede plek is verleende gesag dit wat die woorde sê: dit is gesag wat Christus aan die kerk leen sonder om die besitreg daarvan af te staan of sy eie hoofskap deur Woord en Gees à la Calvyn (Strauss 2010:82) prys te gee. Dit is gesag wat Hy aan die kerk leen op dié voorwaarde: bly by die Bybel as julle met hierdie gesag wil optree, dan staan Ek agter julle. Dan kan die kerk handel in die Naam van die Here en geregverdig aanvoer: So sê die Here HERE (Rom 12:1; Ef 4:17). In die derde plek word hiermee aangedui dat elke kerkvergadering sy eie werksterrein soos verwoord in die kerkorde het en die terrein van die ander vergaderings moet respekteer. Dat kerkwees die saak van die gelowiges saam is, of van 'n geloofsgemeenskap (Ef 3:18), in plaas van net ons afgeskeie groepie, of ek en die Here alleen. Dat elke vergadering as skoenmaker hom by sy lees moet hou omdat dit die taak is waarvoor hy geroep is (NGK 1964:5; Strauss 2010:61).

Teen die agtergrond van die eie aard en gesag van vergaderings in kerkverband loop die gesag en terrein van die kerkraad teenoor meerdere vergaderings nie van die laagste na die hoogste nie (Strauss 2004:113; Pienaar n.d.:30), maar waaier dit op 'n gelyke vlak uit van die bevoegdheid van die kerkraad ten opsigte van die welsyn van die gemeente na die ring, van die ring oor die versorging van die buurgemeentes na die sinode, van die sinode oor die gesamentlike werk van die gemeentes van die streek na die Algemene Sinode en by die Algemene Sinode oor daardie sake wat die betrokke gemeentes as iets gemeenskapliks raak of sake soos die belydenis waaroor hulle saam besluit. Die kerkraad doen sy werk in die gemeente as ' $n$ instansie van meer gelowiges wat vanuit die Woord anti-hiërargies kontrolerend saamwerk met gesag deur Christus verleen, die ring versorg die gemeentes in die buurt as gemeentes in 'n gesamentlike aksie met dieselfde soort gesag en die sinodes werk met hierdie gesag op hulle eie kerkordelik bepaalde tereine. Die gesag van 'n vergadering sluit nie gesag oor ' $n$ ander vergadering op sy terrein in nie, maar gaan oor bevoegdheid op sy eie terrein. By 'n ring en sinodes kan die eie terrein die hantering van appèlle teen die beslissings van ' $n$ kerkraad of ' $n$ mindere vergadering insluit. By toetrede tot die verband stem 'n kerkraad in dat hy in ' $n$ ring of sinode oor die sake van daardie vergadering saam met ander gemeentes op 'n anti-hiërargiese wyse besluit. Boonop word die term 'meerdere vergaderings' nie gebruik om meer gesag aan te dui nie, maar dat meer gemeentes as volledige kerke hier saam vergader (Pienaar n.d.:30; Strauss 2010:53-54).

In sy bekende artikel 21 reël NGKO-62 dat kerkvergaderings alleen kerklike sake en 'wel' op 'n kerklike wyse hanteer. Hierdie artikel spruit uit die DKO-1619 artikel 30 en GKNKO 1959 artikel 29. Die Dordtse Kerkorde van 1619 bevat die Nederlands gereformeerde reël uit die 16de eeu dat kerkvergaderings kerklike sake op 'n kerklike wyse hanteer en GKNKO 1959 voer aan kerkvergaderings hanteer 'kerkelijke zaken ... in overeenstemming met het kerkelijke karakter van deze vergaderingen' (Pont 1981:179; Nauta 1971:126). Waarom dit hier gaan, is dat die NGK sake vanuit die hoek van die kerk as 'n geloofsinstelling met die Woord as die swaard van die Gees opneem en nie reageer soos 'n tipies politieke, nuus-, of handelsinstelling nie. Dat kerkvergaderings so moet praat en moet besluit dat hulle optrede oortuig dat hulle vanuit die kerk kom en op 'n profeties kritiese, priesterlik pastorale én koninklik besliste manier bou aan God se koninkryk hier op aarde oral waar Hy gehoorsaam word. Dat die NGK in die wêreld, maar nie van die wêreld is nie (Strauss 2010:57-62).

\section{Slot}

Die NG Kerkorde 1962 kan ten opsigte van sy hoofstukindelings, sekere vertrekpunte en bewoording beskryf word as die DKO-1619 aangepas by die eise van die dag. Die NG Kerkorde 1962 oor sinodes en die Algemene Sinode kan egter nie deurgaans in dieselfde terme beskryf word nie. Die ooreenstemming wat daar wel is, is geleë in twee sake: elemente van die agenda van 'n NGK-sinode en die kern van die sake op die terrein van die Algemene Sinode.

Ten opsigte van hulle samestelling en afbakening gaan NGKsinodes en die Algemene Sinode grotendeels nié die weg van die DKO-1619 nie. Op die Algemene Sinode het die DKO en sy trapsgewys gereformeerde manier van afvaardiging wel invloed, maar gee 'n liberaal demokratiese benadering gebaseer op die getal gemeentes en predikante, die toon aan. By sinodes gee predikants- en nie gemeentegeoriënteerde norme nie, deurgaans ook 'n ongereformeerde pas in hierdie verband van volledige kerke of gemeentes aan. 
Anders as by ander gereformeerde kerke gebruik die NGK nie konsekwente Nederlands gereformeerde (Dordts gereformeerde) oorwegings by die instelling van sinodes en die Algemene Sinode nie. Dit geld vir hulle afbakening, samestelling én werksaamhede.

\section{Erkenning \\ Mededingende belange}

Die outeur verklaar dat hy geen mededingende belange het nie.

\section{Outersbydrae}

P.J.S. die enigste outeur betrokke by die skryf van die artikel.

\section{Etiese oorwegings}

Hierdie artikel voldoen aan alle etiese standaarde vir navorsing sonder direkte kontak met mens of dier.

\section{Befondsing}

Hierdie navorsing het geen spesifieke toekenning ontvang van enige befondsingsagentskap in die openbare, kommersiële of nie-winsgewende sektore.

\section{Data beskikbaarheidsverklaring}

Data-deling is nie van toepassing op hierdie artikel nie, aangesien geen nuwe data in hierdie studie geskep of ontleed is nie.

\section{Vrywaring}

Die sienings en menings wat in hierdie artikel uitgedruk word, is dié van die outeur(s) en weerspieël nie noodwendig die amptelike beleid of posisie van enige geaffilieerde agentskap van die outeurs nie.

\section{Literatuurverwysings}

Bavinck, H., 1967, Gereformeerde Dogmatiek IV, 5 de druk, Kok, Kampen. Biesterveld, P. \& Kuyper, H.H., 1905, Kerkelijk Handboekje, Bos, Kampen. Bouwman, H., 1985, Gereformeerd Kerkrecht II, 3de druk, De Groot Goudriaan, Kampen. De Jong, O.J., 1987, Geschiedenis der kerk, 11de druk, Callenbach, Nijkerk.

Dreyer, A., 1936, Boustowwe vir die geskiedenis van die Nederduits-Gereformeerde Kerke in Suid-Afrika III, Nasionale Pers, Kaapstad.

Engelhard, D.H. \& Hofman, L.J., 2001, Manual of Christian Reformed Church government, CRC Publications, Grand Rapids, MI.

Kleynhans, E.P.J., n.d., Die kerkregtelike ontwikkeling van die Nederduitse Gereformeerde Kerk in Suid-Afrika 1795-1962, sn., s.I.
Kruger, L.S., Du Plessis, H.L.M., Spoelstra, B. \& Spoelstra, T.T. 1966, Handleiding by die Kerkorde, Pro Rege, Potchefstroom.

Langner, D., 2007, Teen die hele wêreld vry - Koot Vorster, segsman of profeet? Griffel, Pretoria.

Nauta, D., 1971, Verklaring van de kerkorde van de Gereformeerde Kerken in Nederland, Kok, Kampen.

Nederduitse Gereformeerde Kerk (NGK), [1962] 2002, Handelinge van die Algemene Sinode, s.n., s.l.

Nederduitse Gereformeerde Kerk (NGKO), 1964, Kerkorde van die Nederduitse Gereformeerde Kerk, NG Kerk-Uitgewers, Kaapstad.

Nederduitse Gereformeerde Kerk (NGKO), 1974, Kerkorde van die Nederduitse Gereformeerde Kerk, NG Kerkboekhandel, Pretoria.

Nederduitse Gereformeerde Kerk (NGKO), 1986, Die Kerkorde van die Nederduitse Gereformeerde Kerk, NG Kerkboekhandel, Pretoria.

Nederduitse Gereformeerde Kerk (NGKO), 2004, Die Kerkorde van die Nederduitse Gereformeerde Kerk, Lux Verbi, Wellington.

Nederduitse Gereformeerde Kerk (NGKO), 2007, Die Kerkorde van die Nederduitse Gereformeerde Kerk, s.n., s.I.

Nederduitse Gereformeerde Kerk (NGKO), 2011, Die Kerkorde van die Nederduitse Gereformeerde Kerk, s.n., sl.

Nederduitse Gereformeerde Kerk (NGKO), 2015, Die Kerkorde van die Nederduitse Gereformeerde Kerk, s.n., s.l.

Nederduitse Gereformeerde Kerk (NGK), 2016, Jaarboek van die Ned Geref Kerke, s.n., s.l.

Nederduitse Gereformeerde Kerk in Zuid-Afrika (NGK in ZA), 1857, Acta Kaapsche Synoden 1824-1847, G.J. Pike, Kaapstad.

Nederduitse Gereformeerde Kerk in die Oranje-Vrystaat (NGK-OVS), 1937, Handelinge van die Sinode, s.n., s.l.

Nederduitse Gereformeerde Kerk in die Oranje-Vrystaat (NGK-OVS), 1999, Kerkorde, s.n., s.I.Pienaar, G., n.d., Die regsposisie van die Gereformeerde Kerke in SuidAfrika, EFJS, Orkney.

Pont, A.D., 1981, Die historiese agtergronde van ons kerklike reg, HAUM, Pretoria.

Protestantse Kerk in Nederland (PKN-KO), 2003, Kerkorde en ordonansies, Boekencentrum, Zoetermeer.

Roussouw, P., 1979, Kerkvergaderings, NG Kerkboekhandel, Pretoria.

Rutgers, F.L., 1971, De geldigheid van de oude kerkenordening der Nederlandse Gereformeerde Kerken, Ton Bolland, Amsterdam.

Smit, C.J., 1984, God se orde vir sy kerk-'n beskouing oor kerkorde. NG Kerkboekhandel Transvaal, Pretoria.

Strauss, P.J., 1989, 'Geen kerk oor 'n ander ...', Acta Theologica 9(1), 1-14.

Strauss, P.J., 1999, 'Die goedkeuring van kerkrade vir 'n nuwe verband in die NG Kerkfamilie?', Acta Theologica 19(2), 32-54.

Strauss, P.J., 2004, 'Partikuliere en algemene sinodes: 'n Gereformeerde benadering', Acta Theologica 24(2), 105-126. https://doi.org/10.4314/actat.v24i2.48984

Strauss, P.J., 2005, 'Watter sake hoort by meerdere vergaderings?', In die Skriflig 39(2), 293-310. https://doi.org/10.4102/ids.v39i2.386

Strauss, P.J., 2010, Kerk en orde vandag, Sunmedia, Bloemfontein.

Strauss, P.J., 2017, 'Die klassis en kerkvisitasie in drie kerkordes', In die Skriflig 51(1), a2282. https://doi.org/10.4102/ids.v51i1.2282

Strauss, P.J., n.d., 'Die NG Kerkfamilie in Suider-Afrika: 'n Nuwe kerkverband?', in R. Nel \& H. Du Toit (reds.), Ons pelgrimsreis na eenheid, pp. 92-105, Universiteit van Pretoria, Pretoria.

Van Dellen, I. \& Monsma, M., 1967, The revised church order commentary, Zondervan, Grand Rapids, MI.

Van der Watt, P.B., 1987, Die Nederduitse Gereformeerde Kerk 1905-1975, NG Kerkboekhandel Transvaal, Pretoria.

Visser, J., 1999, Die Kerkorde in praktyk, EFJS, Orkney.

Van Wyk, B.J., 1981, Die presbiteriaal-sinodale kerkbegrip, Kital, Pretoria.

Vorster, J.D., 1960, 'Die Kerkorde vir die Ned. Geref. Kerke: besware daarteen en betekenis daarvan', Nederduitse Gereformeerde Tydskrif September, 12-18. 